\title{
Analysis Student's Mathematical Connection Ability of Class XII MIPA SMA N 1 Ngawen on Statistical Material
}

\author{
Mila Nurul Apriliyani*, Siti Kumawati, Utari Oktaviani, Heny Nugroho \\ Mathematics Education Department Faculty of Teacher Training and Education, Universitas Tidar, \\ J1. Kapten Suparman 39 Magelang 56116, Indonesia, Tel. (0293)364113, Fax. (0293)362438. \\ Email*: milaaprilia34@gmail.com
}

\begin{abstract}
The material in mathematics relates to each other and also relates to daily life. Likewise with statistics is one of the materials on the subject of mathematics that also has a relationship with other sciences, and has been widely used in daily life. This research explains the ability of the mathematic connections of the grade XII students of MIPA SMA N 1 Ngawen on the statistical material. With the aim to know the student's mathematic connection ability. The methods used are qualitative descriptive with research instruments in the form of tests and interviews. The research subject consists of 10 students with an analysis model on this research based on its mathematical connection indicators. From this research gained ability on the indicator linking between concepts on a mathematical material and indicators linking between mathematical concepts with daily life belonging to the high, and low category for indicators The mathematical concept with other sciences.
\end{abstract}

Keywords: mathematic connections, statistics

\section{INTRODUCTION}

Mathematics is a universal science underlying the development of modern technology, has an important role in various sciences, and develops human thought. Statistical. is one of the materials on mathematical subjects that also has a relationship with other sciences. Statistics are also material that is learned from elementary to high school. As well as in everyday life, statistics are also indispensable.

According to the NCTM in Astridayani (2017), it is said that there are five basic skills of mathematics which are the standard of mathematical skills that are problemsolving (problem-solving), reasoning and evidence (reasoning and proof), communication (communications), connections (connections), and representations (representation). The material in mathematics relates to each other and also relates to everyday life. Therefore, a person's ability to connect between units is indispensable in solving mathematical problems. The ability of a mathematical connection is a person's ability to present internal and external relationships in mathematics, which includes connections between math topics, connections with other disciplines, and connections in everyday life. According to Ramdhani (2016) When students are able to relate mathematical ideas, the mathematical understanding will be more profound and longer-lasting as they are able to see the linkages between topics in mathematics, with contexts other than mathematics, and with Everyday life experience. The purpose of this research is to know the mathematical connection of students of the class XII MIPA SMA Negeri 1 Ngawen on the statistical material.
There are five process standards adopted by the National Council of Teachers of Mathematics (NCTM). The five standard processes are troubleshooting (problem-solving), reasoning and evidence (reasoning and proof), communication, Connection, and representation (representations). One of the five standards of the process is the mathematical connection capability. According to the English Great dictionary, the ability to have the meaning of capacity; Proficiency Power. The connection has the meaning of relationships that can facilitate (launch) all matters (activities). While mathematically is concerned with mathematics or mathematics. A mathematical connection can be said as a relationship between concepts related to mathematics.

According to the NCTM in Asrtridayani (2017), the mathematical connection capability is the ability of learners to connect mathematical ideas and to understand the interconnectedness of these ideas. According to Rohendi and Jojon in Rahmanti (2018), The mathematical connection capability is a person's ability to present internal and external relationships in mathematics, which includes connections between mathematical topics, connections with other disciplines, and Connections in everyday life. (Rohendi \& Dulpaja in Gunur, 2019) Mathematical connection capability is one of the most important learning objectives for students because math topics are intertwined with each other as well as other disciplines. So in this research, use 3 indicators to measure the ability of mathematical connections students of Grade XII MIPA SMA N 1 Ngawen on the statistical material, namely: 1) linking between concepts in a single mathematics material. 2) Connect between mathematical concepts with other 
fields. 3) Connect between mathematical concepts to solve problems in everyday life.

Consciously or not, statistics have been widely used in everyday life. Statistics originated from the statistical word stating the data collection, number or not numbers compiled in tables and or diagrams. So statistics is knowledge or science related to the ways of data collection, data processing or analysis and withdrawal of conclusions based on data collection and analysis conducted (Sudjana, 2005). Statistics can be interpreted as a science that specifically develops number processing techniques, learns about data and ways to analyze it (Inayah in Wulansari, 2019).

The material used as a reference in this research is the statistical material taught in the high school grade XII semester 1. That includes the size of the data centration, layout size, and size of data propagation. In this research, the material used as a matter is merely the material size of the data centering and the size of the layout.

\section{MATERIALS AND METHODS}

The study uses a descriptive method with a qualitative approach. With the data retrieval techniques use tests and interviews with the subject of research. Before conducting research, the author determines the subject first. The subject in this study was 10 students of grade XII MIPA SMA Negeri 1 Ngawen which were taken randomly. After obtaining the subject, the research subject was given the mathematical connection capability test. Then interviews to students who have been elected to learn about the students ' understanding of the mathematical connection capability test and to match the data between student work test results on the answer sheet with which students Expressed in interviews so that researchers can find out how the students ' mathematical connections are capable of statistical material. Further analysis of data on data obtained from the test of mathematical connection capabilities and interviews that have been conducted. The final step is to make a conclusion to the data analysis results.

\section{RESULTS AND DISCUSSION}

Here is a question that is used as a test instrument to measure the ability of the mathematical connections of students in grade XII MIPA SMA N 1 Ngawen.
1. The top quartile of the above histogram data is...

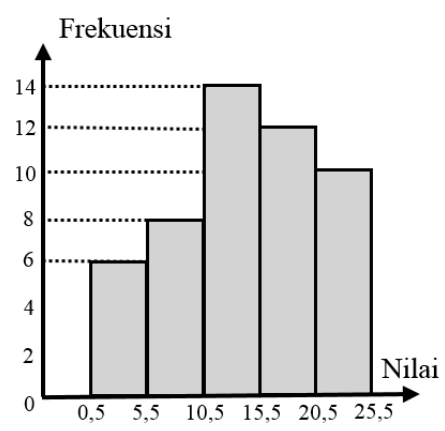

2. The following is the data of research results of several chili plants that are still healthy based on the number of fertilizers given each week.

\begin{tabular}{ll}
\hline Fertilizer (In grams) & frequency \\
\hline $3-6$ & 3 \\
$7-10$ & 5 \\
$11-14$ & 7 \\
$15-18$ & 9 \\
$19-22$ & 2 \\
$23-26$ & 3 \\
$27-30$ & 1 \\
\hline
\end{tabular}

So how many fertilizers should be given to chili plants every week so that chili pepper grows healthy?

3. Last year, a monthly salary of 5 people employees in thousands of rupiah as follows: 480, 360, 650, 700, 260. This year their salary increased $15 \%$ for the previously paid less than Rp 500.000 and $10 \%$ for the previously paid more than Rp 500.000. The average of their monthly salary increase is...

The following is the value of the results of the statistical test 10 students of Grade XII MIPA SMA N 1 Ngawen who became the subject of research.

\begin{tabular}{|c|c|c|c|c|c|c|}
\hline \multirow[b]{2}{*}{ No. } & \multirow{2}{*}{ 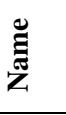 } & \multicolumn{3}{|c|}{ Value } & \multirow{2}{*}{ 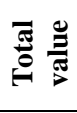 } & \multirow{2}{*}{ ్ㅗㄹ } \\
\hline & & $\begin{array}{c}\text { Indicator } \\
1 \\
\end{array}$ & $\begin{array}{c}\text { Indicator } \\
2 \\
\end{array}$ & $\begin{array}{c}\text { Indicator } \\
\mathbf{3} \\
\end{array}$ & & \\
\hline 1. & $\mathrm{~S} 1$ & 70 & 30 & 100 & 200 & 66,67 \\
\hline 2. & $\mathrm{~S} 2$ & 100 & 50 & 100 & 250 & 83,33 \\
\hline 3. & S3 & 100 & 30 & 100 & 230 & 76,67 \\
\hline 4. & S4 & 70 & 70 & 100 & 240 & 80 \\
\hline 5. & S5 & 40 & 30 & 15 & 85 & 28,33 \\
\hline 6. & S6 & 90 & 30 & 100 & 220 & 73,33 \\
\hline 7. & S7 & 100 & 30 & 35 & 165 & 55 \\
\hline 8. & S8 & 100 & 70 & 100 & 270 & 90 \\
\hline 9. & S9 & 100 & 70 & 15 & 185 & 61,66 \\
\hline 10. & $\mathrm{~S} 10$ & 40 & 70 & 100 & 210 & 70 \\
\hline \multicolumn{2}{|c|}{ Total } & 810 & 460 & 765 & & 684,99 \\
\hline \multicolumn{2}{|c|}{ Averages } & 81 & 46 & 76,5 & & 68,49 \\
\hline
\end{tabular}


The following is a distribution of the mathematical connections capability of grade XII students of MIPA SMA N 1 Ngawen on the material based on the test value.

\begin{tabular}{llll}
\hline $\begin{array}{l}\text { Proficiency } \\
\text { level }\end{array}$ & $\begin{array}{l}\text { Value } \\
\text { range }\end{array}$ & Subject & $\begin{array}{l}\text { Number of } \\
\text { subject }\end{array}$ \\
\hline Very less & $0-36$ & S5 & 1 \\
Less than & $37-46$ & - & 0 \\
Enough & $47-68$ & S1, S7, S9 & 3 \\
Good & $69-84$ & S2, S3, S4, S6, S10 & 5 \\
Very good & $85-100$ & S8 & 1 \\
\hline
\end{tabular}

After conducting tests on the subject, interviews with the subject are then conducted based on the test answer. The following interview test results are grouped by mathematical connection indicators.

\section{Linking between concepts in a single mathematics material.}

Based on the results of the test, I obtained as many as 8 out of 10 subjects that have been able to connect the concept in one mathematical material.

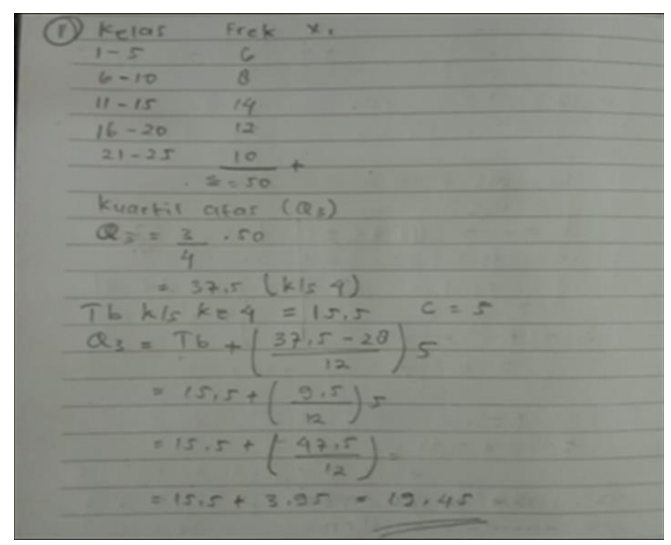

Figure 1. Answer to Question No. 1 of S2.

It is seen one of the answers of the subject that can connect the graph-shaped problem into a group distribution table for easy counting. Then for 1 subject of 8 subjects that can relate material, answer number 1 by filling the three quartiles, while in question only ask the upper quartile or $\mathrm{Q}_{3}$. When asked at the time of the interview the subject also replied that what was asked in question was to look for $\mathrm{Q}_{1}, \mathrm{Q}_{2}$, and $\mathrm{Q}_{3}$. So it can be concluded that the subject is already able to connect the concept in one material because the subject's answer is correct, only the subject is less thorough in reading the problem.

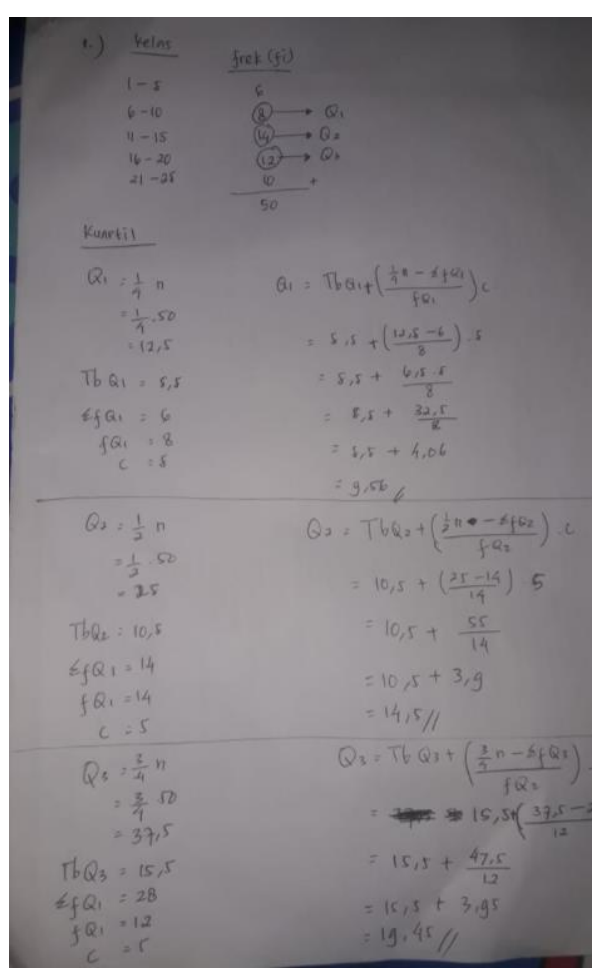

Figure 2. The answer to question No. 1 of S6.

Then 2 other subjects said forgot the notation of the top quartile at the time of the interview. The two answered $\mathrm{Q}_{1}$ for question number 1 , while the top quartile notation was $\mathrm{Q}_{3}$.

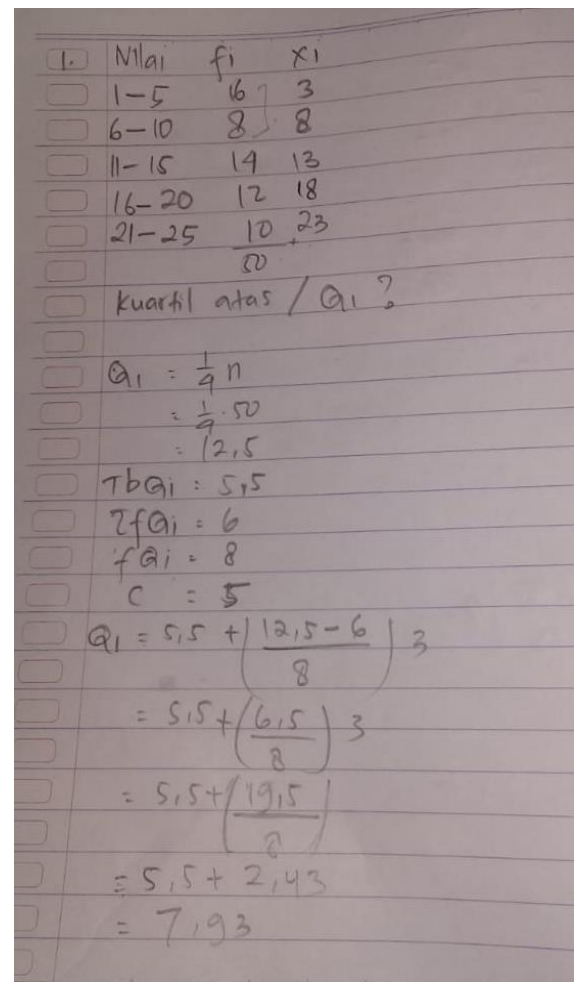

Figure 2. The answer to question No. 1 of S5.

Then, based on the interviews made to each subject, it can be concluded that the average student that is used 
as the subject can explain the answer well and according to what is being done. Researchers have also concluded that the level of the students ' mathematical skills in indicator 1 is good, as most students can link between concepts in one mathematical material, which can work on the questions stated in the graph.

\section{Linking between mathematical concepts with other fields.}

In the second indicator, researchers choose the question related to the field of natural sciences. So that the subject is expected to understand the purpose of the problem expressed in the concept of natural sciences and work on the question according to the order of questions. Then based on the test results, obtained 5 out of 10 subjects capable of linking between mathematical concepts with other fields.

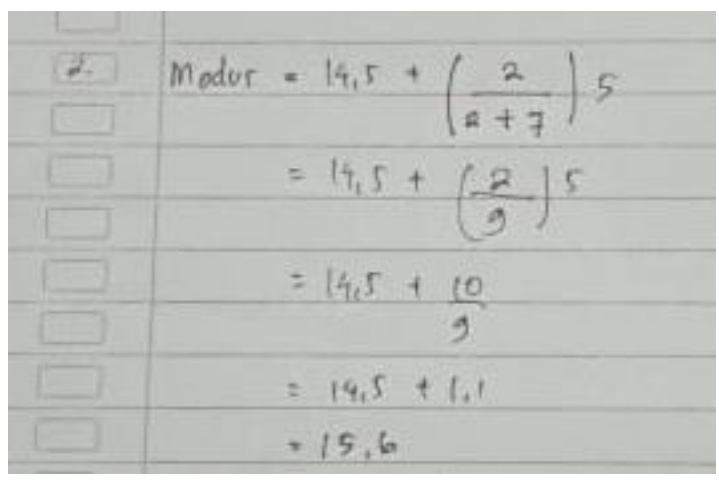

Figure. 4. The answer to question number 2 from S4.

However, 2 of the 5 subjects were only answered until the range of fertilizers that were supposed to be given without finding a large number of fertilizers to be administered using the mode formula. When interviewed the subject that answered the range says that the given range is enough to make the plant grow healthy. Figure 4.

Figure. 5. The answer to Question No. 2 of S9.

Then 1 among the 5 subjects understands the purpose of question number 2 is to look for mode when interviewed subjects also understand what is the mode. However, when answering the problem, the subject responds to the mode in the median section of the number of frequencies divided by two. When interviewed, the subject says that the frequency shown in the matter expressed the amount of fertilizer each week. So that the researcher considers the subject to be able to connect between mathematical concepts with other sciences, just do not understand the purpose of the question.

5 other subjects of 10 subjects, less able to connect between mathematical concepts with other sciences because the answers are given are not by the command of the question. Some answer looking for the average S1 and S6. When the interview, S1 replied not to know what to answer, so answer it with the average formula. Then for S6 says that in question was told to find the average use of fertilizer. Some answer the median looking for S3 and S5. When the interview, both subjects said it did not know and in answering, so it filled the median. Then another subject of S7 answered Q3 and said that problem number 2 was told to look for the mode, then the subject answered Q3 because it was confused to answer what. Figure 5. Jawaban soal nomor 2 dari S9.

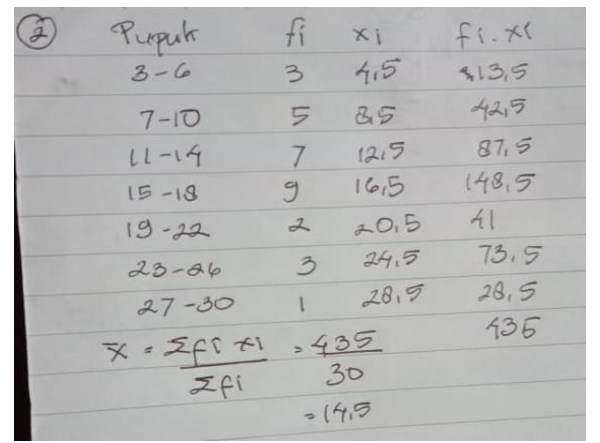

Figure 6. The answer to Question No. 2 of S1 answered on average.

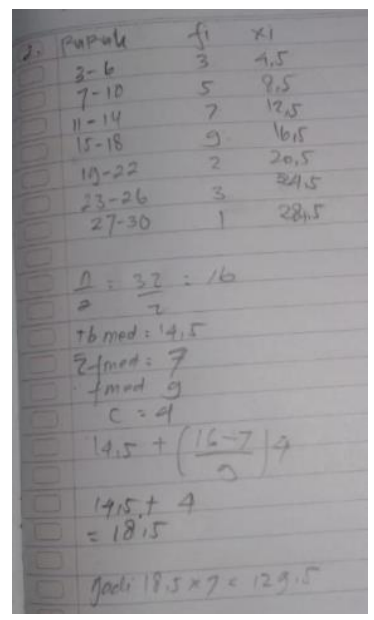

Figure 7. The answer to question number 2 of the S5 answered.

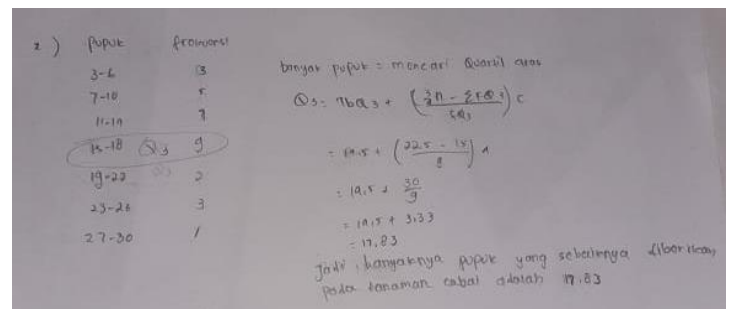

Figure 8. Answer to Question No. 2 of S7 answered Q3.

Based on the results of the interview, it can be concluded that some students can well explain what is in the test. But all subjects are aware of the relationship between mathematical concepts and other sciences. Thus, the students ' mathematical connections are still 
lacking, because some other students who have not been able to answer when they are still struggling in understanding the problem. Then for most of the subject's answers regarding related subjects are biology, chemistry, and SCIENCE.

\section{Linking between mathematical concepts to solve problems in everyday life}

In this third indicator, the researcher chooses a question that has to do with life in a factory or office. The problem is discussed about the average salary increase of employees. Based on the test results, obtained 7 out of 10 subjects capable of linking mathematical concepts to solve problems in everyday life.

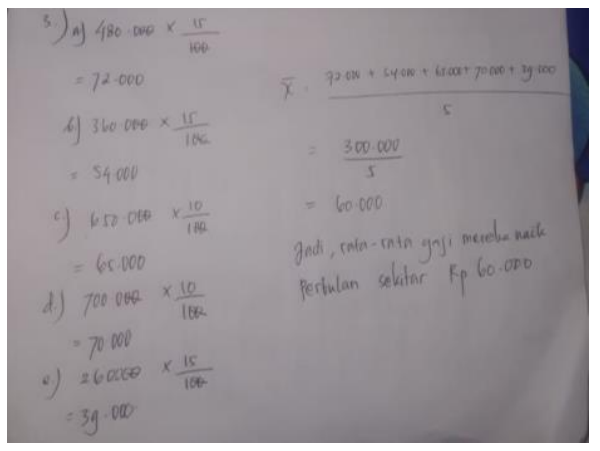

Figure 9. The answer to Question No. 3 of S6.

Visible subjects have understood the intent of the problem so that it can calculate employee salary increase. The subject can also work on the question by looking for the average increase in his salary. However, 3 out of 10 other subjects still lack a sense of question and answer with another formula. The subject of the S5 answered using an average deviation when the subject interview said he forgot the formula and when guided air to rework the subject still trouble. Furthermore, the researcher concluded that the subject level of the connection is low so that it can not understand the problem

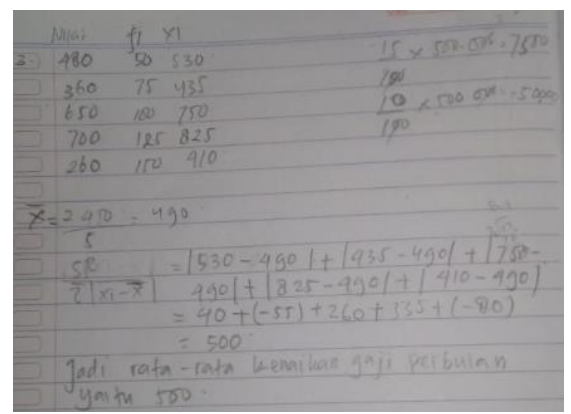

Figure 10. The answer to Question No. 3 of S5.

Next on the S7 subject, the subject has understood the question and answer intent using the average formula. But the operation systematics are less precise so the results are not as desired. The subject displays a problem with the group form of distribution table, while it should be unnecessary. At the time of the interview, the subject said that he was confused when seeking a salary increase. So to find the average difficulty.

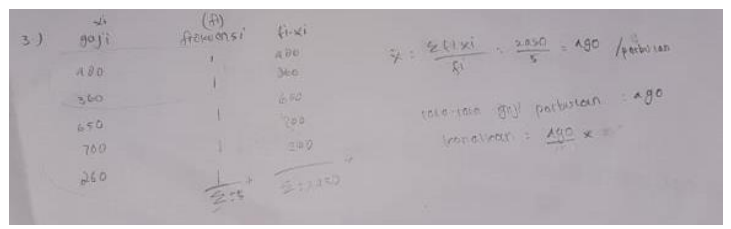

Figure 11. Answer to Question No. 3 of S7.

As for the subject of S9, which answers question number 3 without being known using what formula. However, when the subject interview says that the percentage in the problem is a salary increase, the subject does not count the wage, but its percentage.

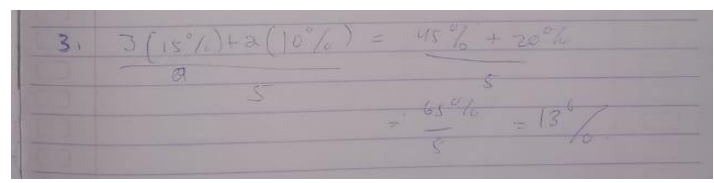

Figure 12. The answer to question number 3 of S9.

Based on the results of the interview, the average student who made the subject can well explain what was done during the test. Researchers also concluded that all subjects knew the relationship between mathematical concepts and daily life. As for students who have not been able to work properly when guided very easily understand the problem because of the skill level of mathematical connection is quite high.

Based on the discussion above, it can be concluded that the mathematical connection capability of grade XII students of MIPA SMA N 1 Ngawen on the statistical material is as follows:

1) Average mathematical connection capability students of Grade XII MIPA SMA N 1 Ngawen based on the test results of 68.49 , while the average mathematical connection capability in each indicator is 81 to connect between mathematical concepts on one material, 46 To connect between mathematical concepts with other sciences, and 76.5 to connect between mathematical concepts and everyday life

2) Each indicator can be concluded as follows

a. Linking between mathematical concepts to a single material

The average student who used to be the subject can explain the answer well and according to what is done. The level of mathematical skills of grade XII students of MIPA SMA N 1 Ngawen on indicator 1 includes good because most students can connect between concepts in one mathematical material that can work on the questions stated in the chart.

b. Linking between mathematical concepts with other sciences 
Some students can well explain what is held at the time of the test. All subjects know the relationship between mathematical concepts with other sciences, just to change them to mathematical sentences is still difficult. The ability of the mathematical connection of grade XII students at MIPA SMA N 1 Ngawen on indicator 2 is still low, as some other students who have not been able to answer correctly while being mentored are still struggling in understanding the problem.

c. Linking between mathematical concepts and everyday life

The average student being made a subject can well explain what is done during the test. All subjects are aware of the relationship between mathematical concepts and everyday life. The ability of the mathematical connection of grade XII students at MIPA SMA N 1 Ngawen on indicator 3 is quite high because other students who have not been able to answer correctly when mentored is easy in understanding the problem.

\section{CONCLUSION}

Based on the results of the interview, the average student who made the subject can well explain what was done during the test. Researchers also concluded that all subjects knew the relationship between mathematical concepts and daily life. As for students who have not been able to work properly when guided very easily understand the problem because of the skill level of mathematical connection is quite high

\section{ACKNOWLEDGEMENTS}

In the completion of this paper, the authors have the support of various parties, therefore on this occasion the author thanks to:

1. Fadhilah Rahmawati S. Pd., M. Pd. As a course for the School of Mathematics education Problematics provides encouragement and input to the authors.

2. All parties in the SMAN 1 Ngawen who have helped smooth the preparation of this paper

\section{REFERENCES}

Astridayani, Amelinda. 2017. Analisis Kemampuan Koneksi Matematis Peserta Didik Kelas VII SMP Negeri 31 Semarang pada Materi Perbandingan. Skripsi: Universitas Islam Negeri Walisongo Semarang

Gunur, Bedilius dkk. 2019. "Vocational School Students' Mathematical Connections in Cooperative Learning with Open Ended Approach". Daya Matematis; Jurnal Inovasi Pendidikan Matematika 7(2): 127-138

Kamus Besar Bahasa Indonesia

Rahmanti, Suci Amalina. Dkk. 2018. Analisis Kemampuan Koneksi Matematis pada Pokok Bahasan Statistika Berbasis Lesson Study for Learning Community. Kadikma 9(1):41-51

Ramdhani, Marlisa Rahmi dkk. 2016. Analisis Kemampuan Koneksi Matematis Siswa Kelas VII SMP Negeri 1 Kembaran Materi Bangun Datar. Prosiding Seminar Matematika dan Pendidikan Matematika: 403-414

Sudjana. 2005. Metoda Statistika. Bandung: Tarsito

Wulansari, Thania dkk. 2019. "Pengaruh Model Pembelajaran Berbasis Masalah Pada Materi Statistika Terhadap Kemampuan Penalaran Statistis Siswa". AKSIOMA; Jurnal Matematika dan Pendidikan Matematika 10(1):35-47 